\title{
Forstår du meg?
}

Senhøstes 1996 ble jeg oppringt fra avdelingsoverlegen ved et norsk sykehus. Han tilbød meg jobb som turnuslege fra januar. Jeg minnet om at jeg ikke snakket norsk - noe som for øvrig var åpenbart $i$ telefonsamtalen vi hadde. Den vekslet mellom svært haltende svensk (fra min side), haltende tysk (fra hans side) og noe engelsk. «Det skal gå så fint, ikke noe problem,» sa han. Jeg fikk ikke norskopplæring, men i stedet personsøker fra første dag og et klapp på skulderen fra hyggelige kolleger. Så var jeg alene på vakt, med ansvar for hele avdelingen. Jeg slet både med å forstå og å gjøre meg forstått. Hver eneste dag vurderte jeg å slutte, men hva skulle jeg gjøre hvis jeg sluttet? Jeg hadde ingen annen stilling i Norge, ingen inntekt, ingen oppholdstillatelse (den er knyttet til jobb), ingen jobb i hjemlandet. Og hvilke sjanser hadde jeg til å få annen jobb i Norge hvis jeg sa opp, lot mine vakter stå ubesatt og satte mine kolleger i en vanskelig situasjon? Det gikk bedre etter hvert, jeg kom meg igjennom. Men jeg ønsker ingen en slik opplevelse, verken pasienter eller leger.

Nevn språkferdigheter og utenlandske leger, og mange har en historie eller flere å fortelle. Ikke så rart, kanskje, ettersom antall leger med utenlandsk statsborgerskap i Norge har økt de siste årene. Av landets 20000 leger under 67 år har om lag 3000 utenlandsk statsborgerskap. Omtrent 1000 kommer fra Norden, like mange fra «gamle» EU-land, og den siste tredelen kommer fra andre land (1). Når saken slås opp i mediene, er det som regel problemer det handler om. Vi hører lite om alle de utmerkede utenlandske kollegene som gjør en nødvendig og god jobb i norsk helsevesen.

I årtier ble utlendinger som forsøkte å få autorisasjon i Norge, rutinemessig avvist. Hovedargumentene var frykt for arbeidsledighet blant norske leger og at det ikke var behov for de utenlandske (2). I 1930-årene ble dette en vond historie, da desperate kolleger på flukt fra Mellom-Europa møtte en kald skulder i Norge (3). 1994 ble et vendepunkt. EØS-avtalen trådte i kraft, og leger fra EØS-land kunne søke om autorisasjon i Norge uten at helsemyndighetene kunne stille krav om språkkunnskaper (4). «Helsetilsynet ser dette som en uønsket konsekvens av EØS-avtalen, idet slike krav er viktige for å sikre kvaliteten i norsk helsevesen [...] Betydningen av god kommunikasjon, skriftlig og muntlig, med pasienter og medarbeidere, i all legevirksomhet, kan ikke understrekes nok,» påpekte helsedirektøren (4). Et tungt ansvar ble lagt på arbeidsgiver, som heretter ble ansvarlig for at legene hadde tilstrekkelige språkferdigheter. Det gikk som det måtte gå. Ti år senere uttalte Jørgen Holmboe i Helsetilsynet (5): «I enkelte utkantkommuner har fanden spist fluer fordi alternativet til en lege har vært ingen lege.»

Gjennom årene har saken bølget frem og tilbake. I 1999 var det legemangel i Norge, og helseminister Dagfinn Høybråten vurderte å fjerne språkkravene også for leger utenfor EØS-området (6). Legeforeningen har foreslått å etablere en nasjonal ordning, der arbeidsgivere må kreve gjennomføring av særlige norskkurs før man ansetter utenlandske leger. Slike norskkurs skulle ha et nasjonalt ensartet innhold og nivå (7). Myndighetene har ikke ønsket dette. At ansvaret for å stille språkkrav er lagt på arbeidsgiver, er en administrativ enkel løsning. Da spiller det visst mindre rolle at dette fører til ulik praksis (8). Det er symptomatisk at tidligere statssekretær Libe Rieber-Mohn i Arbeids- og inkluderingsdepartementet kommer unna med sin uttalelse: «Min personlige erfaring med utenlandske leger er at de snakker veldig godt norsk» (9). Kort sagt kan man si at lite har skjedd siden 1994 - med ett unntak. Fra 2006 er det blitt stilt språkkrav til turnusleger. Bakgrunnen var en konkret sak ved Sørlandet sykehus der fire turnusleger fra EØS-landene Ungarn og Østerrike ble vurdert å ha så dårlige norskkunnskaper at de ikke fikk påbegynne tjenesten (10). Foreløpig siste ord i saken ble sagt i 2008. Da vedtok Stortinget at det ikke skulle innføres obligatorisk norskprøve (11).

Leger som ikke behersker norsk, gir opphav til misforståelser som kan få alvorlige konsekvenser. Det er avgjørende for et velfungerende helsevesen at språkkunnskaper sjekkes og at man ev. tilbyr norskkurs ved ansettelse av leger og annet helsepersonell. Dårlige språkkunnskaper er ikke forenlig med forsvarlighetskravet i helsepersonelloven. Hvem bør så ha ansvar for språktesting? Det er opplagt at dette ikke bør overlates til det enkelte sykehus eller kommune, da det vil skape vanskelige interessekonflikter mellom akutte behov for personale på den ene siden og forsvarlige kommunikasjonsferdigheter på den annen side. Testing av språkferdigheter må løftes til et overordnet nivå. Statens autorisasjonskontor for helsepersonell har allerede spesifikke krav for språkferdigheter før lisens gis til utenlandske turnusleger. Videre har Det medisinske fakultet, Universitet i Oslo ansvar for testing av medisinske ferdigheter (såkalt medisinsk fagprøve) for leger fra land utenfor EØS. Det er derfor nærliggende å utvide disse ordningene til ikke bare å omfatte hhv. turnusleger og leger fra land utenfor EØS-området, men alle utenlandske leger.

Gode språkferdigheter er ikke bare påkrevd for pasientenes og medarbeidernes skyld. Det er også viktig for å beskytte de utenlandske legene mot altfor store utfordringer, frustrasjoner og uheldige hendelser som kan sette dype spor. Det kan være mange grunner til at utenlandske leger søker jobb i Norge. For noen er årsaken arbeidsledighet eller andre uheldige omstendigheter i hjemlandet. De takker kanskje ja til jobb i Norge selv om språkferdighetene ikke er gode nok. Når alternativet til en jobb i Norge er ingen jobb, er det ikke bare fanden og arbeidsgiver som spiser fluer.

\section{Michael Bretthauer}

medisinsk redaktør

\section{Litteratur}

1. Den norske legeforening. Leger < 67 år i Norge etter statsborgerskap 2001-09 august. www.legeforeningen.no/id/78708 (30.9.2009).

Stæng døren straks! Tidsskr Nor Lægeforen 2003; 123: 586

3. Hem E, Børdahl PE. En «nød som ord ikke kan beskrive» - leger på flukt til Norge 1939-40. Tidsskr Nor Lægeforen 2001; 121: 3568-73.

4. Alvik A. Godkjenning av leger fra EØS-landene. Tidsskr Nor Lægeforen 1994; 114: 1403 .

5. Lia K, Stormark K. Akuttmedisinsk kommunikasjonssentral (AMK) ba kommunelegen rykke ut, men legen skal ikke ha forstått hva AMK var. Nå risikerer han å miste autorisasjonen. VG 12.9.2004: 12.

6. Johansen PA. 800 ubesatte legestillinger i Norge: Vurderer å fire på norsk-krav. Aftenposten (morgenutgaven) 25.5.1999: 4

7. Den norske legeforening. Høring - Utredning av helsepersonellovens autorisasjonsordning. www.legeforeningen.no/id/127276 (30.9.2009).

8. Thomassen KM. Språkkrav til leger. Tidsskr Nor Lægeforen 2006; 126: 2152

9. Sødal H. Vil skjerpe språk-kravene for leger. Aftenposten 10.5.2009: 8. www.aftenposten.no/nyheter/iriks/article3068067.ece (30.9.2009).

10. Bakken C. Krever språktest av turnusleger. Tidsskr Nor Lægeforen 2006; 126: 1112.

11. Stortinget. Helsepersonelloven og alternativ behandlingsloven www.stortinget.no/nn/Saker-og-publikasjoner/Saker/Sak/?p=38920 (30.9.2009). 